Article

\title{
Beyond Religious Rigidities: Religious Firmness and Religious Flexibility as Complementary Loyalties in Faith Transmission
}

\author{
David C. Dollahite ${ }^{1, *}$, Loren D. Marks ${ }^{1}$, Kate P. Babcock ${ }^{1}$, Betsy H. Barrow ${ }^{1}$ and \\ Andrew H. Rose ${ }^{2}$ \\ 1 School of Family Life, Brigham Young University, Provo, UT 84602, USA; loren_marks@byu.edu (L.D.M.); \\ katepatterson7@gmail.com (K.P.B.); betsy001hughes@gmail.com (B.H.B.) \\ 2 Department of Sociology, Anthropology, \& Social Work, Texas Tech University, Box 41012, Lubbock, TX \\ 79409-1012, USA; Andrew.Rose@ttu.edu \\ * Correspondence: David_Dollahite@byu.edu
}

Received: 17 January 2019; Accepted: 10 February 2019; Published: 15 February 2019

\begin{abstract}
Research has found that intergenerational transmission of religiosity results in higher family functioning and improved family relationships. Yet the Pew Research Center found that $44 \%$ of Americans reported that they had left the religious affiliation of their childhood. And $78 \%$ of the expanding group of those who identify as religiously unaffiliated ("Nones") reported that they were raised in "highly religious families." We suggest that this may be, in part, associated with religious parents exercising excessive firmness with inadequate flexibility (rigidity). We used a multiphase, systematic, team-based process to code $8000+$ pages of in-depth interviews from 198 Christian, Jewish, and Muslim families from 17 states in all 8 major religio-cultural regions of the United States. We framed firmness as mainly about loyalty to God and God's purposes, and flexibility as mainly about loyalty to family members and their needs and circumstances. The reported findings provided a range of examples illustrating (a) religious firmness, (b) religious flexibility, as well as (c) efforts to balance and combine firmness and flexibility. We discuss conceptual and practical implications of treating firmness and flexibility as complementary loyalties in intergenerational faith transmission.
\end{abstract}

Keywords: intergenerational transmission of religion; parenting; religious youth; parent-youth relationships

\section{Introduction}

Many religious parents desire to pass their own religious beliefs, practices, and commitments on to their children. Indeed, intergenerational transmission of religious belief is a well-established part of family studies (Bengtson et al. 2013; Spilman et al. 2013). Given the American penchant for change, including religious change, perhaps it is also not surprising that a 2009 study conducted by the Pew Research Center found that $44 \%$ of Americans reported that they had left the religious affiliation of their childhood (Pew Research Center 2009). But what may be surprising is that in a 2016 Pew Research Center survey, $78 \%$ of the expanding group of those who identify as religiously unaffiliated ("Nones") reported that they were raised in "highly religious families" (Pew Research Center 2016). In other words, nearly half of Americans do not retain the faith of their parents-and the great majority of those who have rejected institutional religion altogether were raised by parents who presumably highly valued religious identity and commitments. 
Across a number of possible things parents hope their adult children continue to value (e.g., values, religion, politics, education, hobbies, traditions), each child likely will hold to some but not others. However, for parents who highly value their religious identity, it can be particularly painful to see children leave that religion behind or leave faith altogether (Bengtson et al. 2013). There are a number of possible reasons why people raised in highly religious homes and families would chose not to be formally religious themselves. Many of those reasons may have little or nothing to do with how parents acted toward their children in relation to religious things. However, one possible reason for intergenerational retreat from religion is that parents did not strike a healthy balance between devoted adherence to religious belief and practice (i.e., religious firmness) and willingness to adapt their religious devotion to the needs, challenges, and circumstances of family members (i.e., religious flexibility). In this study, we provide an in-depth exploration of the issues of firmness and flexibility in religious belief and practice among a racially and regionally diverse sample of religiously devoted families.

Despite some clear examples to the contrary, the empirical literature indicates that the effects of religion on marriage and family life are generally positive (Marks and Dollahite 2017; Walsh 2009). However, some processes around religious involvement have been found to be harmful to marriage and family relationships. Recent work details the realities that religion involves both help and harm in family life (Dollahite et al. 2018). One idea that has been repeatedly forwarded by social scientists is that rigidities in religious practice are problematic (Burr et al. 2012). What has not been adequately investigated are the processes that lead to rigidities at the nexus of religion and family relationships. Are there ways of being firm and consistent in religious matters that are positive for marriages and families? Are there ways of integrating firmness with flexibility in religious beliefs and practices that provide the greatest amount of good and the least amount of harm (Dollahite et al. 2018)?

\section{Definition of Terms}

Before moving to a review of the relevant literature, we briefly define five central terms.

Religious beliefs. Personal or family ideals, interpretations, and expectations based in religious ideology (e.g., doctrine, theology, scripture, tradition). Personal and family religious beliefs may or may not align with the "official" doctrines of a given faith community.

Religious practices. Personal or family religious rituals and traditions that involve some kind of patterned individual or family action (e.g., reading sacred texts, prayer, attending religious services). Personal or family religious practices may or may not align with the "official" practices (rituals, and traditions) taught or expected by a given faith community.

Religious firmness. Loyalty to God and devoted adherence to those things that are believed to represent or uphold God such as religious beliefs and practices.

Religious flexibility. Loyalty to family members that results in a principled or pragmatic willingness to adapt (at least to some extent) religious beliefs and practices to better meet perceived familial needs, challenges, and circumstances.

Integrating firmness and flexibility. A process that integrates firmness and flexibility in religious beliefs and practices in an attempt to honor both loyalty to God (and that which serves to represent or uphold God) and loyalty to family members (and that which meets their needs, challenges, and circumstances).

\section{Review of the Literature}

Herein, we review relevant literature touching on the issues of (a) intergenerational transmission of religion, (b) parenting style, and (c) family processes, particularly as they pertain to firmness and flexibility in religious beliefs and practices. 


\subsection{Intergenerational Transmission of Religion}

A 20-year longitudinal study by Spilman et al. (2013) found that intergenerational transmission of religiosity was associated with higher quality of family relationships and family functioning. They concluded, "All in all, the results suggest that religiosity promotes competent family functioning across generations ... and was positively associated with observable attributes of family relationships" (772).

Many parents wonder how to best transmit their religious beliefs and values to their children and how to help their children have a desire to maintain these values through adolescence and into adulthood. Many studies have been conducted on how to effectively transmit religious values from parents to children (Bao et al. 1999; Myers 1996). Parental behavior has been identified as an important factor in transmitting values to adolescents (Bengtson et al. 2013; Flor and Knapp 2001; Kim-Spoon et al. 2012). Children often are observant of their parents' actions and values, including to what extent they are consistent-or firm-in their religious beliefs and practices. Dudley and Dudley (1986) found that conflict between parents or between parent and child can inhibit transmission of values, while intimacy in the home facilitated children internalizing values. Similarly, a recent landmark, three-decade, longitudinal study with more than 3,000 participants found that warmth and closeness between parent and child significantly predicted whether children continued in the parents' faith-a finding that held for both mother-child and father-child relations (Bengtson et al. 2013).

Across studies, it appears that when parents found a balance between emotional support and control with adolescents, they were more likely to be successful in transmitting their religious values. If parents were rigid in their approach to religion, their children were more likely to become disaffiliated with their parents' religion as adults (Hansen 1998).

Empirical work on family rituals has offered additional insight. Although family ritual typically benefits individuals and relationships (Chelladurai et al. 2018; Fiese et al. 2002; Marks and Dollahite 2012), additional empirical support for the danger of excessive religious rigidity is offered by a study that found that compulsory family worship was more detrimental than no family worship at all (Lee et al. 1997). It appears possible that a major cause of parent-parent and parent-child conflict over religious matters may stem from unhealthy levels of firmness (rigidity) and/or unwillingness to manifest appropriate kinds of flexibility in religious belief, practice, and ritual.

A study by Gane (2014) that examined parent to adolescent faith transmission found that (a) meaningful relationships with mentors within the adolescent's church and (b) parents openly sharing their faith with their children were both major contributors to transmitting faith to adolescents. Additional positive transmission influences identified in other studies include helping youth learn the stories of their religious heritage, encouraging youth to develop a personal relationship with God, providing opportunities for youth to engage with other members of the religious congregation, strengthening parent-child relationships, parental modeling of religious commitment, fostering connections between youth and religious leaders, and engaging in religious conversations with youth (Dollahite and Thatcher 2008; Smith and Denton 2005). One review has suggested that in adult-youth religious conversations, parental listening may be the most influential form of communication (Marks and Dollahite 2017). When asked what they consider the most important things for them to be in relation to their children, religious parents have identified being an example, authentic, and consistent to provide support, love, and help, and to teach religious values, traditions, and identity (Dollahite et al. 2019).

Laird et al. (2011) further noted that some types of religious commitment (God, faith tradition or denomination, scripture or sacred texts) were more important than others at different times, depending on the developmental stage of the adolescent or the family system. These shifts in relative influence can occur because of familial changes during an adolescent's life or because of the developmental processes of the adolescent. However, each of these commitment types seem to help transmit religious values to adolescents. Families apparently need to be flexible due to normative growth and change in family 
members and circumstances but also need to be responsive to non-normative changes and stressors (Walsh 2009). The issue of responsiveness is an important feature of parenting style, discussed next.

\subsection{Parenting Styles}

The type of parenting style that parents employ can be helpful or detrimental in transmitting faith to their children. Gane (2014) found that "affectionate independence is the optimal parenting style as it relates to Christian commitment and denominational loyalty" (p. 47). Also, excessively strict parental control has been found to be negatively related to church attendance in the adult years (Vermeer et al. 2012). On a related note, Ellison and Sherkat (1993) found that many Conservative Protestants had more of an authoritative style of parenting, where they valued obedience from their children but also valued their children's autonomy. Some Catholic participants tended to be closer to an authoritarian style of parenting and highly valued obedience but were less supportive of autonomy (although there was significant variation within denomination).

An authoritative parenting style has been shown to be the most likely way to encourage (lasting) religious participation and involvement in children. Children are also more likely to both adopt and maintain religious values similar to their parents if the parent-child relationship is warm and close (Bao et al. 1999; Bengtson et al. 2013). Children who reported distance from their parents were less likely to hold parent-similar religious values and beliefs (Kim-Spoon et al. 2012). When parents practiced warm, affirming, and respectful (authoritative) parenting, children were more likely to continue in their parents' religious traditions, practices, and beliefs. Recent qualitative work has similarly emphasized that parental belief-behavior congruence or "practicing what you preach" is also a profound and salient influence because children tend to believe what they see over what they are told (Marks and Dollahite 2017; see also Vermeer et al. 2012). Conversely, perceived belief-behavior incongruence and parental hypocrisy both tend to dispel ongoing faith involvement as children grow into emerging adulthood, although exceptions have been documented (Marks and Dollahite 2017). Longitudinal, mixed-methods research further indicates that parents who have inter-faith marriages, experience divorce, or practice ambivalent or mixed-message parenting are also significantly less likely to see their children continue in parents' religion (Bengtson et al. 2013).

Most major religions emphasize qualities of kindness, patience, other-orientation, peace-making, as well as striving to understand and serve others. Thus, it is possible that if children, teens, and young-adult children of religious parents perceive that their parents consistently placed loyalty to God and divine law unresponsively above loyalty to the real or perceived needs of family members (e.g., serving in the faith community to the level of familial neglect), children may be less likely to follow in the faith-based footsteps of their parents (Kim-Spoon et al. 2012).

In sum, studies indicate that it is important for parents to have a warm and consistent parenting style, and for them to be congruent in their modeling of faith in order for religious practice to be optimally transmitted to their children. Even so, these combined characteristics constitute only a marginal probability (about 56\%), not a guarantee (Bengtson et al. 2013).

\subsection{Family Processes}

According to Olsen's Circumplex Model, balanced family systems usually function better than imbalanced family systems (Olson 2000). Using this model, Schrodt (2005) found that family expressiveness was positively associated with adaptability and cohesion within the family. When family members communicated with each other, they were more likely to adapt well to different situations, which can be helpful when it comes to religious beliefs, practices, and rituals (Colaner et al. 2014). However, a study among Orthodox Jews in Israel found that the Circumplex Model did not necessarily apply to them and their family functioning because these Orthodox Jews highly valued the familial transmission of religious behaviors and beliefs, which made a high degree of control adaptive and normative for their families. This noted exception may indicate variations in the ideal blend of firmness and flexibility across religio-cultural contexts (Pirutinsky and Kor 2013), a 
possibility that begs additional inquiry into how religious beliefs and practices are applied in family life across cultures (Dollahite and Marks 2018; Marks and Dollahite 2018).

Tamara Hareven, co-developer of life course theory with Glen Elder, frequently wrote about the importance of making allowances for the life course-acknowledging that what might be ideal and attainable at one stage of the life course may be burdensome and difficult at another stage. Although Hareven's work (Hareven and Trepagnier 2000) focused on macro-level and community-level cultural, historical, and economic forces (with religion being rarely mentioned), some narratives from our participants seem to capture and reflect life course patterns in religious practices that may call for such "allowances." Indeed, life course shifts such as marriages, births, children's schedules, teenagers, adult caregiving, health problems, and other factors may tend to promote or hinder certain religious practices depending on family circumstances and resources. Some degree of flexibility in religious practice may be beneficial, if not essential.

Finally, a substantial literature exists on the negative consequences of religious "rigidity." Little, if any, work has been done on the processes around and the potential benefits and problems associated with the idea of "religious firmness" (strong, consistent loyalty to God) in connection with religious parenting.

\section{Method}

\subsection{Participants}

The sample for this study included 198 families (476 individuals) from the Abrahamic faiths (Judaism, Christianity, Islam). The sample consisted of religiously and ethnically diverse couples and families from all eight major religio-cultural regions of the United States (Silk and Walsh 2008). This study purposively sampled religious persons and families in a two-stage selection process. First, clergy were contacted and asked to identify marriage-based families with children who were committed to and involved in their faith. Second, recommended families were contacted to determine willingness to participate. Among more difficult-to-access faiths (e.g., Islam, Orthodox Judaism), participant referral sampling was sometimes employed. In terms of affiliation, the sample includes a total of 148 Christian families (from more than 15 denominations), 30 Jewish families (including Hasidic, Modern Orthodox, Conservative, and Reformed), and 20 Muslim families (including Sunni and Shia). The final sample included 20+ denominations. More than half of the sample were from various religious minorities (Marks et al. 2018)

Given their level of attendance (most reported "at least weekly"), monetary contribution (Mean $=7 \%$ of income), hours spent in religious activities (Mean $=11$ hours per week), and given that families were recommended by their religious leaders as being "strong in their faith" and "successful ... in their family relationships," we consider this sample of interviewed families to be exemplars (see Damon and Colby 2013). According to (Bronk et al. 2013), "the exemplar methodology is a sample selection technique that involves the intentional selection of individuals, groups, or entities that exemplify the construct of interest in a particularly intense or highly developed manner" (p. 2). They argue that exemplar research allows study of persons or groups at the "upper ends of development" as well as "not only what is but also what is possible with regard to the development of a particular characteristic" (p. 1). Our purpose in interviewing families that were religious exemplars was to discover how families that were committed to their faith drew from religious belief and practice in marriage and parenting.

Ethnic/Minority families comprised more than half (51\%) of the overall sample of 198 families ( $\mathrm{N}=476$ individuals). Sampled minorities included African American, Asian American, East Asian, Latino, Middle Eastern, Native American, and Pacific Islander families. 
Geographically, participant families were from 17 states in all 8 major religio-cultural regions in the nation, including: the Mid Atlantic (6\%; DE, MD, PA), Midwest (2.5\%; OH, WI), Mountain West (3\%; ID, UT), New England (16\%; MA, CT), Northwest (12.5\%; OR, WA), Pacific (12.5\%; CA), the South/Gulf Coast (39.5\%; FL, GA, LA), and Southern Crossroads regions (7.5\%; KS, OK). Further, the families represented a wide range of socioeconomic and educational levels. In summary, the sample is characterized by: (a) religious diversity, (b) high levels of religious commitment, (c) rich racial and ethnic diversity, (d) geographic and regional diversity, and (e) a wide range of socioeconomic status.

Despite being a sample of religious and family exemplars, like all religious families, participants experienced a variety of relational and religious challenges (Dollahite et al. 2019).

\subsection{Interviewing}

Handel (1996) has indicated that family research is often based on a single individual representing the family, but he contends that this is not "family research" in the truest sense. Handel has stated, "No [single] member of any family is a sufficient source of information for that family" (346). In the present study, mothers, fathers, and children were interviewed in order to gather multiple perspectives on a variety of family relationships.

We wanted to explore both successes and challenges that religious families experience, therefore intensive interviewing was chosen as an appropriate method. We strived to address and check our biases in the interviewing processes as well. Each interview question was pretested to identify any potential problems. Each question was open-ended, and many had follow-up questions to clarify and add depth to the initial responses given.

Interviews were conducted as a couple. Babbie (2004) stated that joint interviewing "frequently brings out aspects of the topic that would not have been anticipated by the researcher and would not have emerged from interviews with individuals" (303). Seymour et al. (1995) argued that joint interviewing reveals different kinds of knowledge held by each person and produces more complete data as persons fill in each other's gaps and memory lapses.

Accordingly, interviewers encouraged wives and husbands to respond to each question and to comment on or add to the other's response. Interviews included much interchange, correcting, challenging, and adding to spouse's comments. Consistent with research involving couple interviews conducted by Holmberg et al. (2004), the wives corrected or added to comments made by their spouse more often than husbands. Interviews typically lasted about two hours. Questions focused on connections between religion, marriage, and family life. Core concepts emerged from systematic, team-based analyses of the data, as discussed next.

\subsection{Coding Process}

The initial ideas around firmness and flexibility emerged from repeated analyses of the transcripts. It became clear that religious families varied in how firmly or flexibly they approached their beliefs and practices. We then decided to intentionally and systematically explore the issues of firmness and flexibility. There were no specific questions about either firmness or flexibility on the questionnaire. These ideas emerged from inductive processes.

Coding occurred in three phases. First, we developed a codebook for the concepts of firmness and flexibility. To create the codebook, we followed formats described by MacQueen et al. (1998) and Bernard and Ryan (2010). Each pair of complement elements was developed in further detail based on our literature review and previous coding and analysis. In the first phase of coding (main coding phase), we trained eight advanced undergraduate coders, who coded interviews for all 198 families. We used NVIVO 10 and 11 software to assist with coding procedures and data management. Each student was paired with another student to review each other's codes and they discussed discrepancies as a check and balance system and to ensure inter-rater reliability (Marks 2015). Data analyses from all 198 families are included in Table 1 which summarizes the main concepts that were coded. 
Table 1. Concepts: Firmness and Flexibility in Religious Practices and Religious Beliefs.

\begin{tabular}{lccc}
\hline Themes & Religious Firmness & Religious Flexibility & $\begin{array}{c}\text { Integrated Firmness and } \\
\text { Flexibility }\end{array}$ \\
\hline $\begin{array}{c}\text { Religious Family } \\
\text { Practices }\end{array}$ & $\begin{array}{c}\text { Firmness in regular } \\
\text { worship (e.g., attend } \\
\text { worship services weekly) }\end{array}$ & $\begin{array}{c}\text { Flexibility in regular worship (e.g., } \\
\text { go to church some weeks if } \\
\text { convenient, engage in weekly } \\
\text { rituals when convenient) }\end{array}$ & $\begin{array}{c}\text { Consistent and firm in worship or } \\
\text { other rituals. Some flexibility } \\
\text { depending on situation (e.g., } \\
\text { modify ritual to fit your children's } \\
\text { needs but still carry it out) }\end{array}$ \\
Religious Beliefs & $\begin{array}{c}\text { Firmness in beliefs about } \\
\text { church doctrine or } \\
\text { practices }\end{array}$ & $\begin{array}{c}\text { Flexible in beliefs and have } \\
\text { unorthodox interpretations of } \\
\text { many/some doctrines and practices }\end{array}$ & $\begin{array}{c}\text { Know and seek to honor the } \\
\text { religion's beliefs and practices but } \\
\text { with adaptations that allow } \\
\text { religion to work for them and } \\
\text { their family }\end{array}$ \\
\hline
\end{tabular}

The accounts from Integrated Firmness and Flexibility, Flexibility, and then Firmness were reanalyzed to look for specific themes within these quotes. The accounts were reanalyzed until theoretical saturation was achieved. There were four to five main themes found throughout the accounts in each of the three categories [(1) Firmness, (2) Flexibility, (3) Integrated Firmness and Flexibility]. The two foci in this article include: (a) religious family practices and (b) religious beliefs. In Table 2, consistent with the aim of providing a data audit trail (Patton 2002), we present the number of coded excerpts for each of those categories.

Table 2. Frequencies and Percentages: Firmness and Flexibility in Religious Practices and Beliefs.

\begin{tabular}{cccc}
\hline Themes & $\begin{array}{c}\text { Religious Firmness } \\
\mathbf{3 3 5}\end{array}$ & $\begin{array}{c}\text { Religious Flexibility } \\
\mathbf{1 2 1}\end{array}$ & $\begin{array}{c}\text { Integrated Firmness and Flexibility } \\
\mathbf{6 1}\end{array}$ \\
\hline Religious Practices & $101(17.4)$ & $62(25.1)$ & $29(22.8)$ \\
Religious Beliefs & $234(40.2)$ & $59(23.9)$ & $32(25.2)$ \\
\hline
\end{tabular}

\section{Results}

The two themes we will address and illustrate in this section are: (1) Firmness and Flexibility in Religious Family Practices and (2) Firmness and Flexibility in Religious Beliefs. To facilitate links between the data and thematic concepts, we will italicize certain words or phrases in participant comments that capture the essence of the theme being illustrated. We will also present some data regarding parents' concern (or lack of concern) involving religious transmission.

\subsection{Theme 1: Firmness and Flexibility in Religious Family Practices}

There was a wide range of responses from the 476 participants as they discussed their approach to religious practices and rituals at the family level. Some reported more firmness (perhaps even rigidity) in their practices and rituals, while others conveyed a more relaxed approach. A few explained, often in a confessional style, that they had been so flexible with family ritual that some rituals had ceased altogether. There were many, however, who had seemed to find a healthy balance, often referencing both firmness and flexibility in the same comment regarding daily or weekly family religious practices. In connection with Theme 1 (Religious Family Practices), we will respectively discuss (a) religious firmness, (b) religious flexibility, and (c) integrating firmness and flexibility.

Firmness in Family Religious Practices: "[He] never missed a night." For many families, their sacred rituals were not optional and had reportedly become an important part of their family life and who they were. Kira ${ }^{1}$, a Lutheran mother, shared how some family rituals were important to her; "I can't imagine not going to church on Sundays. And as ritual as that is, I just can't imagine not [going]." Claire, a Latter-day Saint mother, described how rituals have helped her family:

1 All participants' names have been replaced with pseudonyms. 
We [picked] a "family scripture" [verse]. ... We used it, and we read it together every Monday night, and it would kind of help the [kids], as they went into the teenage years, with all the challenges that were there, all the challenges that are out there for kids. [The family verse] had "watch" and "pray" in it, and it really helped strengthen our children and our family.

Faith, a Catholic mother, also shared how rituals have benefited her family:

We pray together as a family. Martin is so good about [praying] at bedtime. [He] has never missed a night, praying with the children, the boys in their room, because they're in the same room, and then the girls. I think for them it's routine. And for them, [those prayers mean] being a part of the family. I think that evens their day out. It's something they've learned to expect, and that Daddy's always going to be there, or Momma, to get that constancy, that consistency too.

Calvin, an African American, Baptist father, shared his stance on Sunday rituals when he said,

Yes, first of all, it's just going to church on Sundays. I mean, I think that's a practice that my family has and it's important. I think it's important for my kids. [Now] there are Sundays when they don't want to go, [but still] I said, "We have to, you have to go to church." I mean, that's just a practice of this family.

Manuela, a Latina, Lutheran mother, shared her view on church attendance:

One thing we've tried to do, [we've taught our kids], "As long as you live under our roof, you will go to church with us." If not every single week, then absolutely, as much as possible. [That is how] we grew up. There comes a time when you move out of the house or you're away from home, where you are going to stray, more than likely. You're not going to go to church, but our feeling is that if we have instilled it in them for 18 or 19 years, they may stray, but they're going to go back. ... They're going to [come] back ... [and when they do], it will be there. They'll know that it's important for their family, to do the same thing.

Charlotte, a Presbyterian mother, shared a similar story:

[One of the kids] made a comment a lot about, "How come we have to go to church? None of my other friends do. Why are we the only ones?" Which we're not. What do I say? "Because that's what we do. We're going to church and you'll be better off for it. So, get out of bed [and] get in the car."

These accounts, especially the italicized portions, illustrate firmness in religious rituals and/or observance. Next we will discuss flexibility in connection with family-level religious practices.

Flexibility in Family Religious Practice: "It changes all the time." Many comments from participants emphasized the importance of flexibility in religiously-oriented family practices to them or their families. Some families were flexible with their religious practices and rituals because they (or at least one member of the family) valued other things more than religious observance. Martha, a Lutheran mother, said, "[My son], there's probably a couple of times that we dragged him to church and he wanted to do other things, or sports related things. But mostly we let him do his sports instead of church." Abigail, a Reform Jewish mother, shared her family's flexibility with rituals:

And because we're tired on Friday night, we don't get to synagogue as much as we want to. And, because of other time commitments, there's just never enough time to do as much as maybe we should for the Jewish community.

Jim, a Caucasian, Latter-day Saint father, had seen their weekly ritual of Family Home Evening $\mathrm{ebb}$ and flow over the years and noted specific difficulties keeping the ritual firmly in place when children hit the teen years (a recurring struggle across faiths). He said, 
[E]specially when kids were younger ... we tried to hold (family home evening) once a week ... [W] ] would discuss Scriptures, principles, play a game or two, sing a few hymns, have a [treat] ... I think we were pretty consistent when the kids were small, [but] we didn't do as well as the kids got older ... [but] we were pretty consistent ... [but those were] not quite as rigidly structured as the Sunday worship service.

The hallmark of more flexible families was that rituals did not always have to be done weekly or daily, and the way in which the ritual was done reportedly changed over time. Brian, a Catholic father, shared his family's experience with prayer when he said, "We have, as the family has grown, we've sort of changed. ... [The] prayer that we used to say at night prayer, we don't say it as often." For Brian's family, changes in style and frequency had both occurred. Jamie, a Jehovah's Witness mother, described her experience with being flexible in the amount of time she spent on religious involvement outside the home. She explained,

I'm a strong believer in [being sensitive to] circumstances... [W] hen I was younger and I had ... our babies, the time I could spend in the ministry was nothing like what I can do now. And I feel that there are many families with different circumstances. So what we excel in now, maybe ten years ago I didn't have that luxury to excel in.... So, it changes all the time.

Next, we will look at integrations of firmness and flexibility in religious family practices. Many participants' families reportedly strived to find a balance between the two.

Integrated Firmness and Flexibility in Religious Practices: “We usually read our scriptures together [but] you don't need to ... do a certain thing [every time]." Many families expressed a balance between being firm in their approach to rituals, and also being flexible as changes arose. They emphasized the importance of religion and rituals, while adapting them to work with their family goals. Charlene, a Latter-day Saint mother, stated,

We usually [read our scriptures together] in the evening and we're either around the table or in the family room or living room, wherever we happen to be, wherever most people happen to be at the moment. And partly, we do that on purpose because we want them to feel like anywhere you go, you can read scriptures. You don't need to go and sit at the table or do a certain thing and when we read it, we have each person read however many verses we're going to read. Right now, we went through reading a chapter at a time and I found that we weren't really learning much, so what we do now is we [have each family member read] two scripture [verses] each.

This family was consistent in their family practice of studying scriptures, but they were also flexible as a family on how, when, and where the study was done.

Banafsha, an East Indian, Muslim mother, illustrated a similar point in connection with salat (Islamic prayer five times daily):

We don't want to delay the prayer of anybody. If they are studying, they can pray in their room and keep studying [and] not wait for the other ones because you see, we wash up before we pray. So, that was a reason, we didn't want to make it hard for anybody. But I think that the good thing was when you go to anybody's room, it's time for prayer, they either have already prayed, or they are praying.

For Banafsha's family, prayer is non-negotiable, but where and (with some latitude) when the prayer takes place is negotiable. Ariella, a Conservative Jewish mother, shared a similar experience about her children's desire to perform their family sacred rituals. She said,

We do the same rituals for our holidays and all our Sabbath activities and you know, a lot of times we have to nag them and pull them into things, but if we DON'T do something or if something is missed or if we say, "We are not going to do Shabbat," [then] they say, 
"What do you mean we're not doing it!?" [with animation] ... They'll get mad that we don't do it. They're upset because it's not the way it usually is. They get upset if we don't hallow [the Sabbath]. It's very interesting. Sometimes they act like we are annoying them by dragging them through the ritual but if we don't have it there for them they get upset by it.... The religion provides a lot of strength and comfort and structure.

As was the case in most of the Jewish families we interviewed (Marks et al. 2017), children in Ariella's family made it clear that some degree of consistency and predictability in religious rituals is important. Of course, when those children are older they may call on their parents to provide greater flexibility in timing and length of religious rituals if the rituals begin to compete with other valued activities in youth's lives.

Having examined firmness and flexibility in connection with religious family practices in Theme 1 , we now turn our attention to firmness and flexibility in connection with religious beliefs in Theme 2 .

\subsection{Theme 2: Firmness and Flexibility in Religious Beliefs}

Many of the participants we interviewed expressed firmness in the area of religious beliefs. That is, they were quite orthodox in how they approached the religious beliefs of their respective Abrahamic faith (and/or denomination). Many participants held at least some of their religious beliefs to be rooted in doctrines or practices that were divinely revealed and thus non-negotiable and not subject to significant personal or family adaptation. This has been called a "vertical" (divine) sense of morality and religion, as opposed to a "horizontal" (or socially constructed) view (Burr et al. 2012; Shichida et al. 2015). We explore this firmness of religious belief next.

Firmness in Religious Beliefs: "There is no discussion." Many participants, couples, and families were quite firm when it came to certain beliefs of their religion. They viewed following divinely revealed commandments as vital and departing from them was not an option. These families tended to look to their religion for guidance instead of secular texts or ideas.

Sabir, an East Indian Muslim father said, "If it is something that has already been prescribed religiously, then there is no discussion. Things like this, at least in our family, we tend to go back to the religion."

Mei, a Chinese Christian mother shared her beliefs on marriage that stem from the Bible when she said, "This is the principle; we could not change the order."

Jerome, an African Methodist father, also shared a Bible-based belief:

And the law we follow, as the Bible says, is "Honor thy father and thy Mother." And I truly believe that. If you have sassy kids, don't bring them around me because I'm not going to play.... You will treat my household as such. We are not going to change.... You are going to abide by the rules or you are not going to come in here.

Some families also expressed that every aspect of their life goes back to their religion and revolves around their religious beliefs. Elsu, a Native American, Christian father reported,

Our religious beliefs—everything we chose; who our kids were allowed to play with ... where they were allowed to go, what they were allowed to partake of, what churches they could go to, who they could affiliate with. Every aspect of life was guided by our faith.

Even though certain religious beliefs or practices may be difficult to follow, some individuals expressed their desire to follow them and honor God. Noor, a Muslim mother, said she was told by one man in her city,

"You know, for your own security, you probably should remove your Hijab, and the girls should remove their Hijab [veil, covering]." And I think that, gaining strength from my religious beliefs, I said, “No, I'm not going to." People have to realize I am Muslim.

Deshi and Jing, a Chinese Christian couple also shared their desire to honor God through action, 
Deshi: One tenth offering is not a problem in our church. We should do according to God's words. Our faith is in God.

Jing: It is God's grace for me to find this job. The one-tenth money is the most meaningful because it is used for God's work.

Having outlined firmness in personal and familial religious beliefs, we now explore flexibility.

Flexibility in Religious Beliefs: “I don't agree ... so I ignore them." Although many participants, like those whose reports were featured in the previous section, focused on firmly grounded, even unalterable, beliefs, other participants described what they believed personally in relation to the official beliefs of their religious institutions. These individuals interpreted doctrine and teachings in varied and adaptive ways that reportedly fit better or made more sense to them and their families. Some spontaneously expressed, without any related questioning, that they did not have the same views as their religion and/or religious leaders on a few (or several) things. A number of participants and families were open to varying, less orthodox interpretations of their religion, and were flexible when it came to believing, partially believing, or thoroughly rejecting some doctrinal or theological or pragmatic elements of their faith. Some of these families seemed to select what they truly believed from their religion and then developed their own beliefs regarding certain issues.

Miriam, a Jewish mother, shared her view about certain Jewish perspectives on gender in worship:

I have a problem with gender roles [in] religion in general, so I ignore them. I don't abide by them or whatever. Like in Orthodox [Judaism], I'm often, not offended, but it's just that I don't agree with the idea of having women and men separated during ceremonies. Women are not allowed on the bemah [podium from which Torah is read] and you can't listen to a woman's solo voice and I just don't believe in that part of it.

Li-Fen, a Chinese Christian mother, shared her opinion on the doctrine of tithing:

We offer money at church. We all know how we should do, everyone should tithe. But this proportion should be flexible rather than fixed because the condition[s] of families are different. Those families which are in difficulties should adjust.

Li-Fens's argument for circumstantial flexibility resonates with Hareven and Trepagnier (2000) scholarly position that allowances should be made for the life course.

Erin, an Episcopalian mother, shared a view and approach to God images that presents a flexible non-orthodoxy that includes a "live and let live" approach to beliefs. Erin reported,

I certainly grew up saying God the Father [but now] there are lots of people at Grace [cathedral] who say "She" instead of "He," and to me those words don't mean enough that I care. I could see, I can see imagery of God as, you know, Father, Protector, Mother, Nurturer, Wind, Life. I don't need an attachment, but I don't object to it. So when somebody says [about] God, "He," that doesn't bother me.

A few participants, however, were not only less than fully reconciled to their faith's "institutional" beliefs, they were diametrically opposed to some beliefs and practices. One Orthodox Jewish father reported that, despite his connection to much of Jewish tradition, some aspects that he perceived as unnecessarily rigid were "anathema" to him. Elijah, another Jewish father, explained that in spite of his high level of both personal and synagogue-level involvement, "I profoundly disagree with institutional Judaism."

Additionally, many Muslim participants (both women and men, wives and husbands) expressed widely varying interpretations of hijab (the Islamic practice of covering) that reflected different levels of flexibility in both belief and practice. Indeed, the variations in our data were substantial enough to allow a recent article on the topic (Alghafli et al. 2017). 
In connection with the theme of flexibility in religious beliefs, participants' views often differed from the traditional views held by their faith. As illustrated, these divergent patterns were evident in connection with gender roles, attitudes towards financial contribution, God images (including, but not limited to, gender), the degree of flexibility that should be permitted in ritual and practice, and how certain beliefs should be translated into practice (e.g., hijab). While these illustrations are a small sample of the 59 total reports related to "flexibility in beliefs," the preceding data indicate that even devotedly religious persons selected as "exemplars" by their own clergy often wrestle with at least some beliefs espoused by their traditions and actively incorporate some level of flexibility in their lived religious experience.

In summary, many of the exemplar (clergy-referred) families we interviewed were quite orthodox in belief and were devoted in their religious practices (i.e., orthopraxy). Many other families, however, were quite flexible in their beliefs, practices, and interpretations of their religion, and introduced moderate to major adaptations. Other families seemed to seek a balance between their beliefs and their faith's viewpoint-a type of negotiated hybrid. We now turn to reports from the data $(\mathrm{N}=32)$ on families that strived to integrate religious firmness and religious flexibility.

Integrated Firmness and Flexibility in Beliefs: "[I] look to the religion and I look into the secular things." A body of empirical data indicates that sacred beliefs can be a beneficial (even profoundly meaningful) coping resource-particularly when these sacred beliefs are shared in couples and families (Marks and Dollahite 2017). For many highly religious families across the Abrahamic faiths, one frequently navigated issue is the extent to which non-religious materials and ideas should be integrated into how the family thinks about various matters, including family relationships themselves.

Yuusif, an East Indian, Muslim father, referenced this choice point when he said,

I do primarily look to the religion; however, I look into the secular things to the extent that if it's going to help me understand the situation we are up against [then I'll use it].... I look at [secular materials] to see how people think.

Tara, a Latter-day Saint mother, shared a similar view. Asked whether she would personally turn to sacred or secular sources in confronting a problem, she reported,

I would read both. I would give more weight to what was said in the religious publication but I would read a lot everywhere, hoping to find [useful information]. With the kids, for example, if there's a problem, I certainly will read the church [sources], but I'll read other things as well.

When individual participants and families were willing to look at different sources outside of religion to help them solve problems, they suggested it was beneficial to them as a whole. This integrated approach, however, raises the question of which source is primary versus secondary. Iffah, an Arab American Muslim mother, discussed primacy when she explained,

Sometimes we even, we have tradeoffs between whether we want to have a religious view of something or have a cultural view of something. [However], for our family, the religious view is the view that we consider first. I would say it is the priority.

Vickie, an Episcopalian mother, shared her views on the Bible as a resource when she said,

Teaching Sunday school to the older kids, you don't have to take the Bible literally. The Bible ... guides us and we need to use it as such, but [we do] not [have] to live literally by it only, because with translations, things can get translated differently.

Wes, a Seventh-day Adventist father, also discussed interpretation and application of scripture:

In some places [in the Bible] it says, "Above all things you should do this." And I think some people would interpret that [as meaning 'Do this,] even at the cost of your family.' Like, 'You have to go here, even if your family will not go with you,' or '[Even] if this will cause major problems in your family [do it anyway].' I wouldn't think that God would want that 
to happen, but to a certain extent, depending upon your family, I would think [you need to be more flexible than that].

In this theme, we have seen some participants and their families exemplify both religious firmness (i.e., referencing sacred religious texts as their primary resource) while also demonstrating religious flexibility in being willing to move beyond sacred resources to also access potentially valuable secular resources.

\section{Discussion}

In this article, we have explored firmness and flexibility among a sample of highly religious exemplar parents. We used a multiphase, systematic, team-based process (see Marks 2015) to code more than 8000 double-spaced pages of in-depth interviews from 198 Christian, Jewish, and Muslim families from 17 states in all 8 major religio-cultural regions of the United States. We framed firmness as mainly about loyalty to God and God's purposes. We defined flexibility as mainly about loyalty to family members and their needs and circumstances. Findings provided examples illustrating (a) religious firmness, (b) religious flexibility, and (c) integration of religious firmness and religious flexibility.

Findings on religious family practices. Many religious parents were quite firm about attending religious services every week. Others were more flexible in their approach to religious attendance and other family religious practices. Flexibility was manifest in their approach to, the frequency of, and the location where religious rituals were practiced. Some families expressed an approach to religious practice that seemed to integrate firmness and flexibility. Often this involved some kind of negotiation with children regarding how to approach religious practices.

Findings on religious beliefs. Similarly, many participants were quite firm about their religious beliefs, indicating they held strictly to doctrines or theologies prescribed by their faith communities as they understood them. Others expressed some degree of flexibility toward their religious beliefs. This flexibility ranged from taking issue with some aspects of orthodox belief to outright rejection (or ignoring) of certain "official" or "traditional" doctrines they found problematic. Such beliefs tended to center on issues around gender, financial expectations, and the extent to which traditional practices are to be followed.

Findings on integrated firmness and flexibility. Others expressed ways that they were firm in their religious beliefs but made some religious allowances as well. A major theme here involved integrating reliance on religious resources (e.g., scriptures, doctrine, clergy) with secular resources (e.g., social science research, self-help books, professional counselors) in efforts to strengthen family relations and solve family problems. Even though flexibility in beliefs can be beneficial to an individual, flexibility could potentially be harmful to the family as a whole if there are conflicting beliefs about religious issues that are viewed as important and/or central.

The parental examples in this study suggest the potential effectiveness of parents integrating firmness and flexibility in daily and weekly family practices, as well as in religious beliefs. In order to instill religious beliefs and to make those beliefs and rituals meaningful, families reported that they thought it was important to be consistent in their rituals and beliefs, but to also leave room to modify or adapt rituals as circumstances changed. A conceptual slogan might be "sometimes bend but don't break." Families expressed that it was important to be flexible with religious practices, rituals, and beliefs when needed, yet firm enough to retain the vital, sacred elements.

Burr et al. (2012) suggested that on a variety of familial topics there seem to exist some principles and helpful practices that come from sacred sources-and other principles and helpful practices that originate or are developed through empirical and social research methods. If Burr and colleagues are correct in their assertion of unique and value-added strengths available in both sacred and social science domains-and they offer support for their position in several topical areas including coping, forgiveness, and prayer-then it may be that families that are willing to "firmly" seek insight from their faith's wisdom literature and "flexibly" seek understanding from high quality social science may be in a position of enviable strength. 


\subsection{Firmness and Flexibility as Complementary Loyalties}

We have framed the processes of religious firmness and flexibility such that each process involves an important kind of loyalty. Thus, religious firmness may be conceptualized as cognitive and behavioral processes (religious beliefs and practices) centered in loyalty to God and that which serves to directly uphold or represent God (e.g., sacred texts, faith tradition, faith community, and divine commandments). Having clearly-defined and deeply-valued religious beliefs and practices suggests that the person and/or family feels a certain degree of sacred loyalty to God and those things believed to reflect or uphold God. This firmness is often manifest in (a) religious beliefs that (due to perceived divine origin) are non-negotiable and not subject to personal abrogation and (b) religious practices that are held sacred and inviolable and thus take precedence over other nonreligious or personal activities. Such practices are often maintained even in the face of personal and familial inconvenience or preferences.

Similarly, religious flexibility may be conceptualized as cognitive and behavioral processes centered in loyalty to family members (and other loved ones) by maintaining sensitivity to their needs, challenges, and circumstances. As we have observed, a "key challenge for [many] American churches in the 21st century will be to find a balance between supporting the standard of marriage-based families that are idealized [by most churches] ... while addressing the pluralistic family realities that confront them" (Dollahite et al. 2004, p. 414). For faith communities and for families themselves, integration between these two complementary loyalties may be needed to optimize personal and family wellbeing in the context of acceptance of divine mandates and expectations.

Commenting on a draft of this study, a long-time colleague, Carol Le Blanc drew related connections between the challenges families face in finding healthy balance and integration between firmness and flexibility in relational and religious life with her work as an expert yogi and yoga instructor. She explained in personal communication with us that in yoga's "mountain pose" there is,

a delicate balance of a firm, grounded base coupled with the flowing gentle movement of breath work together to steady the body and the mind. Too much firmness and we become like tin soldiers, easily brought down by the slightest knock or wind. Too much flexibility and we easily lose the pose or more likely, have difficulty finding the pose in the first place. If we hold too firmly to the goal of achieving a certain outcome, it will almost always elude us. Much like Nathaniel Hawthorne's butterfly, which when pursued, is always just beyond your grasp, but which, if you will sit down quietly, may alight upon you. Conversely, if we are too flexible we may allow ourselves to get carried away by distractions.

(Carol Le Blanc, personal communication, 02/14/2019)

We believe these observations may offer relevant insight to our focal topic. Consistent with research on authoritative parenting styles (that include high levels of both warmth and control), we suggest that parents who faithfully integrate religious firmness and religious flexibility may have the best chance to see their children continue in their faith. We think the findings of this study may imply that religious parents that effectively integrate these complementary loyalties to their God and their family members may be better able to be authoritative, balanced, functional, and healthy in how they attempt to pass their religious beliefs and practices on to the next generation.

Research has emphasized the importance of healthy relationships for successful transmission of religious identity and commitment (Bengtson et al. 2013). Given the inevitable conflicts that occur in religious families (Lambert and Dollahite 2006), it is crucial for religious parents who wish to maintain the kind of relationships that facilitate religious transmission to learn how to draw from religious beliefs and practices to bring relational reconciliation after conflict (Dollahite et al. n.d.).

In sum, we think that (a) religious firmness without religious flexibility may result in religious rigidity, (b) religious flexibility without religious firmness may result in religious haphazardness and loss of sacred beliefs and practices, while (c) religious firmness integrated with religious flexibility is more likely to result in a balanced, healthy style of religious parenting. 


\subsection{Limitations}

This study is subject to the limitations of many qualitative research studies. However, for a qualitative study, the sample is unusually large $(\mathrm{N}=476)$ and geographically diverse (i.e., national). Even so, the sample is neither random nor representative. Further, while the sample is ethnically and religiously diverse, only American families in the Abrahamic faiths were interviewed and the families selected were "exemplars," not average or median congregants. Therefore, findings from an exemplar sample may not be easily generalized to less religious families.

\subsection{Future Research: Beyond Religious Rigidities}

The social sciences have doggedly focused on the problems with religious rigidities for decades. It is time for scholars to become more flexible in how they think about and explore processes around firmness and flexibility in religious belief and practice. As a group, social scientists tend to be fairly irreligious and lean overwhelmingly to the political left (Duarte et al. 2014). Thus, it is not surprising that far more research has focused on the negative consequences of religious rigidities than on the potential benefits of religious firmness appropriately integrated with religious flexibility. We hope this study will be among the first of many to explore these important processes.

\section{Conclusions}

This study may suggest that religious parents who wish the fruits of their faith to be enjoyed by their children and grandchildren need to be firm enough in their faith that they plainly show their loyalty to God (and things that reflect or uphold God) by striving to clearly and consistently incorporate their religious beliefs and practices into family life across time and circumstance. Yet our findings also suggest that strongly religious parents could benefit their children by striving to be flexible enough in how those beliefs and practices are applied in families that they also show their loyalty to their family members by attending to their needs, challenges, and circumstances.

Author Contributions: Conceptualization, D.D. and L.M.; methodology, D.D. and L.M.; validation, D.D. and L.M.; formal analysis, D.D., L.M., and K.B.; D.D., K.B. and L.M.; resources, D.D. and L.M.; data curation, D.D. and L.M.; writing—original draft preparation, D.D., L.M., K.B., \& B.B.; writing-review and editing, D.D., L.M., B. B., and A.R.; visualization, D.D., L.M., \& A.R.; supervision, D.D. and L.M.; project administration, D.D. and L.M.; funding acquisition, D.D. and L.M.

Funding: This research received no external funding.

Acknowledgments: We appreciate funding for this project from the BYU Family Studies Center, BYU Religious Studies Center, and an Eliza R. Snow Grant to the first author as well as a grant to the second author from the LSU Council on Research. We are grateful to the following BYU students for help in coding the data: Hilary Dalton, Toshi Shichida, Kelsie Dean, Stephanie Seaborn, Beda Rose, Rebekah DeBoer, Heather Garbe Venera, JillAnne Jensen, Jordan Kohl, and Naomi Winters.

Conflicts of Interest: The authors declare no conflict of interest. The funders had no role in the design of the study; in the collection, analyses, or interpretation of data; in the writing of the manuscript, or in the decision to publish the results.

\section{References}

Alghafli, Zahra, Loren D. Marks, Trevan G. Hatch, and Andrew H. Rose. 2017. Veiling in Fear or in Faith? Meanings of the Hijab to Practicing Muslim Wives and Husbands in USA. Marriage E Family Review 53: 696-716.

Babbie, Earl R. 2004. The Practice of Social Research, 10th ed. Belmont: Wadsworth.

Bengtson, Vern L., Norella M. Putney, and Susan Harris. 2013. Families and Faith: How Religion is Passed Down Across Generations. New York: Oxford.

Bernard, Russel H., and Gery W. Ryan. 2010. Analyzing Qualitative Data. Los Angeles: Sage.

Bao, Wan-Ning, Les B. Whitbeck, and Danny R. Hoyt. 1999. Perceived Parental Acceptance as a Moderator of Religious Transmission among Adolescent Boys and Girls. Journal of Marriage E Family 61: 362-74. 
Bronk, Kendall C., Pamela E. King, and Kyle M. Matsuba. 2013. An Introduction to Exemplar Research: A Definition, Rationale, and Conceptual Issues. In Exemplar Methods and Research: Strategies for Investigation. New Directions for Child and Adolescent Development. Edited by M. Kyle Matsuba, Pamela E. King and Kendall C. Bronk. San Francisco: Jossey-Bass, vol. 142, pp. 1-12.

Burr, Wesley R., Loren D. Marks, and Randal D. Day. 2012. Sacred Matters: Religion and Spirituality in Families. New York: Routledge/Taylor \& Francis Group.

Chelladurai, Joe M., David C. Dollahite, and Loren D. Marks. 2018. 'The Family That Prays Together': Relational Processes Associated with Regular Family Prayer. Journal of Family Psychology 32: 849-59. [CrossRef] [PubMed]

Colaner, Colleen Warner, Jordan Soliz, and Leslie R. Nelson. 2014. Communicatively Managing Religious Identity Difference in Parent-Child Relationships: The Role of Accommodative and Nonaccommodative Communication. Journal of Family Communication 14: 310-27. [CrossRef]

Damon, William, and Anne Colby. 2013. Why a True Account of Human Development Requires Exemplar Research. In Exemplar Methods and Research: Strategies for Investigation: New Directions for Child and Adolescent Development. Edited by M. Kyle Matsuba, Pamela E. King and Kendall C. Bronk. Hoboken: John Wiley \& Sons, Inc., vol. 142, pp. 13-25.

Dollahite, David C., and Loren D. Marks. 2018. Introduction to the Special Issue: Exploring Strengths in American Families of Faith. Marriage \& Family Review 54: 617-34. [CrossRef]

Dollahite, David C., Loren D. Marks, and Betsy H. Barrow. n.d. Exploring Relational Reconciliation Processes in Christian, Jewish, and Muslim families. Family Relations. Forthcoming.

Dollahite, David C., Loren D. Marks, and Hilary Dalton. 2018. Why Religion Helps and Harms Families: A Conceptual Model of a System of Dualities at the Nexus of Faith and Family Life. Journal of Family Theory $\mathcal{E}$ Review 10: 219-41.

Dollahite, David C., Loren D. Marks, and Michael A. Goodman. 2004. Religiosity and Families: Relational and Spiritual Linkages in a Diverse and Dynamic Cultural Context. In The Handbook of Contemporary Families: Considering the Past, Contemplating the Future. Edited by Marilyn J. Coleman and Lawrence H. Ganong. Thousand Oaks: Sage, pp. 411-31.

Dollahite, David C., Loren D. Marks, and Kaity Pearl Young. 2019. Relational Struggles and Experiential Immediacy in Religious American Families. Psychology of Religion and Spirituality 11: 9-21. [CrossRef]

Dollahite, David C., and Jennifer Y. Thatcher. 2008. Talking about Religion: How Highly Religious Youth and Parents Discuss Their Faith. Journal of Adolescent Research 23: 611-41. [CrossRef]

Duarte, José L., Jarret T. Crawford, Charlotta Stern, Jonathan Haidt, Lee Jussim, and Philip E. Tetlock. 2014. Political Diversity Will Improve Social Psychological Science. Behavioral and Brain Sciences 38: 1-13. [CrossRef]

Dudley, Roger L., and Margaret G. Dudley. 1986. Transmission of Religious Values from Parents to Adolescents. Review of Religious Research 28: 3-15. [CrossRef]

Ellison, Christopher G., and Darren E. Sherkat. 1993. Obedience and Autonomy: Religion and Parental Values Reconsidered. Journal for the Scientific Study of Religion 32: 313-29. [CrossRef]

Fiese, Barbara H., Thomas J. Tomcho, Michael Douglas, Kimberly Josephs, Scott Poltrock, and Tim Baker. 2002. A Review of 50 Years of Research on Naturally Occurring Family Routines and Rituals: Cause for Celebration? Journal of Family Psychology 16: 381-90. [CrossRef] [PubMed]

Flor, Douglas L., and Nancy Flanagan Knapp. 2001. Transmission and Transaction: Predicting Adolescents' Internalization of Parental Religious Values. Journal of Family Psychology 15: 627-45. [CrossRef] [PubMed]

Gane, Barry. 2014. Adolescent Faith That Lasts. Journal of Youth Ministry 13: 42-61.

Handel, Gerald. 1996. Family Worlds and Qualitative Family Research: Emergence and Prospects of Whole-Family Methodology. Marriage E Family Review 24: 335-48.

Hansen, Cheri. 1998. Long-Term Effects of Religious Upbringing. Mental Health, Religion \& Culture 1: 91-111.

Hareven, Tamara K., and Barbara Trepagnier. 2000. Families, History and Social Change: Life Course E Cross-Cultural Perspectives. New York: Routledge.

Holmberg, Diane, Terri L. Orbuch, and Joseph Veroff. 2004. Thrice Told Tales: Married Couples Tell Their Stories. Mahwah: Erlbaum. 
Kim-Spoon, Jungmeen, Gregory S. Longo, and Michael E. McCullough. 2012. Parent-Adolescent Relationship Quality as a Moderator for the Influences of Parents' Religiousness on Adolescents' Religiousness and Adjustment. Journal of Youth and Adolescence 41: 1576-87. [CrossRef]

Laird, Robert D., Loren D. Marks, and Matthew D. Marrero. 2011. Religiosity, Self-Control, and Antisocial Behavior: Religiosity as a Promotive and Protective Factor. Journal of Applied Developmental Psychology 32: 78-85. [CrossRef]

Lambert, Nathaniel M., and David C. Dollahite. 2006. How Religiosity Helps Couples Prevent, Resolve, and Overcome Marital Conflict. Family Relations: An Interdisciplinary Journal of Applied Family Studies 55: 439-49. [CrossRef]

Lee, Jerry W., Gail T. Rice, and V. Bailey Gillespie. 1997. Family Worship Patterns and Their Correlation with Adolescent Behavior and Beliefs. Journal for the Scientific Study of Religion 36: 372-81. [CrossRef]

MacQueen, Kathleen M., Eleanor McLellan, Kelly Kay, and Bobby Milstein. 1998. Codebook Development for Team-Based Qualitative Analysis. Cultural Anthropology Methods 10: 31-36. [CrossRef]

Marks, Loren D. 2015. A Pragmatic, Step-by-Step Guide for Qualitative Methods: Capturing the Disaster and Long-Term Recovery Stories of Katrina and Rita. Current Psychology: A Journal for Diverse Perspectives on Diverse Psychological Issues 34: 494-505. [CrossRef]

Marks, Loren D., and David C. Dollahite. 2012. "Don't Forget Home": The Importance of Sacred Ritual in Families. In Understanding Religious Rituals. Edited by John P. Hoffman. New York: Routledge, pp. 186-203.

Marks, Loren D., and David C. Dollahite. 2017. Religion and Families. New York: Routledge.

Marks, Loren D., and David C. Dollahite. 2018. Surmounting the Empathy Wall: Deep Respect and Holy Envy in Qualitative Scholarship. Marriage \& Family Review 54: 762-73. [CrossRef]

Marks, L. D., D. C. Dollahite, and K. P. Young. 2018. Struggles experienced by religious minority families in the United States. Psychology of Religion and Spirituality. [CrossRef]

Marks, Loren D., Trevan G. Hatch, and David C. Dollahite. 2017. Sacred Practices and Family Processes in a Jewish Context: Shabbat as the Weekly Family Ritual Par Excellence. Family Process 57: 448-61. [CrossRef] [PubMed]

Myers, Scott M. 1996. An Interactive Model of Religiosity Inheritance: The Importance of Family Context. American Sociological Review 61: 858-66. [CrossRef]

Olson, David H. 2000. Circumplex Model of Marital and Family Systems. Journal of Family Therapy 22: 144-67. [CrossRef]

Patton, Michael Q. 2002. Qualitative Research E Evaluation Methods, 3rd ed. Thousand Oaks: Sage.

Pew Research Center. 2009. Faith in Flux. Washington, DC: Pew Research Center, April, Available online: http:/ / www.pewforum.org/2009/04/27/faith-in-flux/ (accessed on 13 February 2019).

Pew Research Center. 2016. Why America's 'Nones' Left Religion Behind. Washington, DC: Pew Research Center, August, Available online: http:/ / www.pewresearch.org/fact-tank/2016/08/24/why-americas-nones-leftreligion-behind/ (accessed on 13 February 2019).

Pirutinsky, Steven, and Ariel Kor. 2013. Relevance of the Circumplex Model to Family Functioning Among Orthodox Jews in Israel. New School Psychology Bulletin 10: 25-38.

Schrodt, Paul. 2005. Family Communication Schemata and the Circumplex Model of Family Functioning. Western Journal of Communication 69: 359-76. [CrossRef]

Shichida, Toshi, David C. Dollahite, and Jason S. Carroll. 2015. How the Perception of God as a Transcendent Moral Authority Influences Marital Connection among American Christians. Journal of Psychology and Christianity 34: 40-52.

Seymour, Julie, Gill Dix, and Tony Eardley. 1995. Joint Accounts: Methodology and Practice in Research Interviews with Couples. New York: Social Research Policy Unit.

Silk, Mark, and Andrew Walsh. 2008. One Nation, Divisible: How Regional Religious Differences Shape American Politics. Lanham: Rowman \& Littlefield.

Smith, Christian, and Melina L. Denton. 2005. Soul Searching: The Religious and Spiritual Lives of American Teenagers. New York: Oxford.

Spilman, S. K., T. K. Neppl, M. B. Donnellan, T. J. Schofield, and R. D. Conger. 2013. Incorporating religiosity into a developmental model of positive family functioning across generations. Developmental Psychology 49: 762-74. [CrossRef] [PubMed] 
Vermeer, Paul, Jacques Janssen, and Peer Scheepers. 2012. Authoritative Parenting and the Transmission of Religion in the Netherlands: A Panel Study. International Journal for the Psychology of Religion 22: 42-59. [CrossRef]

Walsh, Froma. 2009. Spiritual Resources in Family Therapy, 2nd ed. New York: Guilford.

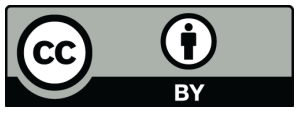

(c) 2019 by the authors. Licensee MDPI, Basel, Switzerland. This article is an open access article distributed under the terms and conditions of the Creative Commons Attribution (CC BY) license (http:/ / creativecommons.org/licenses/by/4.0/). 